\title{
SIMPLIFIED FAMILY TREES OF THE ADMINISTRATORS STUDIED
}

\author{
KARANJA FAMILY \\ KIARII wa Wanjema (grandfather) \\ KARANJA wa Kiarii (father) and Njeri (Nyagitiri) KARANJA (mother) \\ b. 1900 \\ ca. $1893-1986$ \\ and three other wives \\ Charles Kibe karanja and Philomena Ndanga karanja (wife) \\ b. 1931

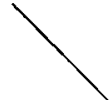 \\ b. 1934 \\ John Mutugu Karanja (son) b. 1954 \\ (Mrs.) Magda Njeri Kamau (daughter) b. 1957 \\ Lawrence KARANJA (son) b. 1959 \\ Lucy Waithira KARANJA (daughter) b. 1961 \\ Thomas Kiarie KARANJa (son) b. 1963 \\ Francis Kanyoni KaRANJA (son) b. 1965
}

\section{MULE FAMILY}

Philip mule (father) $1900-81$

and Ruth KaTUkU (mother) b. 1910

Phoebe Mueni irhau (sister) b. 1931

George Kimeu MULE (brother) b. 1933

Harris Mutio MULE, b. 1936

Josephine Keli kINYUMU (sister) b. 1939

Dr. Judith Mbula BAHEMUKA (sister) b. 1942

Jack Mumo MULE (brother) b 1945

Francis Ndungo MULE. (brother) b. 1947

Daniel Munyao MUle (brother) b. 1950

Violet Kamanthi NTHENGE (sister) b. 1953
Joseph IVITA (wife's grandfather)

Joseph KISUNA (wife's father)

and Teresia MUTHEU (wife's mother)

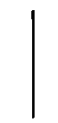

Martha Ngina MULe (wife) b. 1946

Nthenya MULE (daughter) b. 1971

Ndinda MULE (daughter) b. 1983 


\section{MURIITHI FAMILY}

Elijah WaICANGURU (father) and Lydia WANGECI (mother)

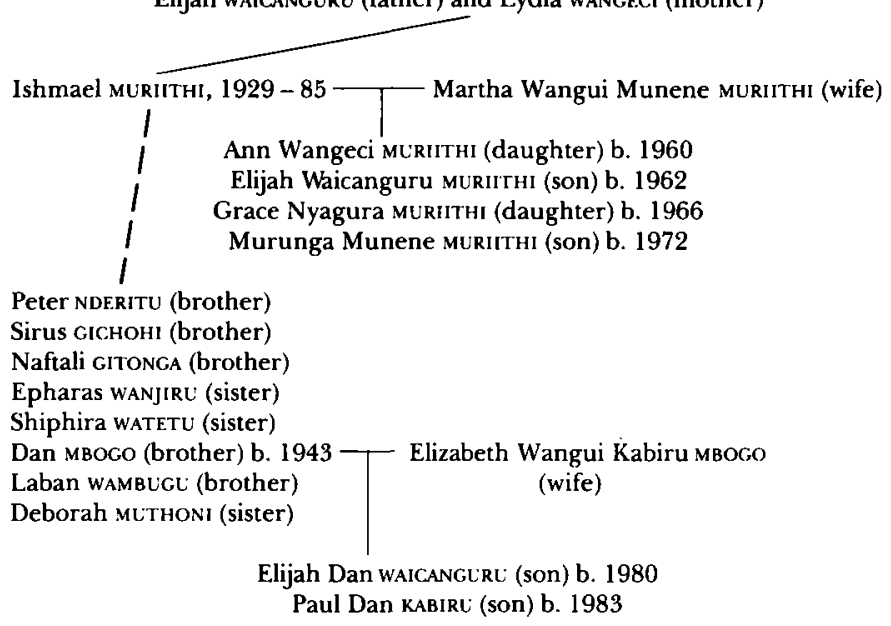

\section{NYACHAE FAMILY*}

Musa NYANDUSI (father) and Pauline Bosibori (mother) b. ca. 1910 ca. $1895-1970$ and multiple other wives

James OIRURIA (brother) b. 1930

Simeon Nyachaf, b. 1932 - and Esther Nyaboke NyaChaE (first wife) b. 1937

Grace Rosemary NYACHAF (daughter) b. 1954 and several other children

and Druscilla Kerubo NYACHAE. (second wife) - 1956 MaTY NYACHAF (daughter) b. 1956

and Martha Mwango NYACHAE (third wife) b. 1940

Charles Ayako NYACHAE (son) b. 1958 Kenneth Bitange NYACHAE (son) b. 1959 and several other children

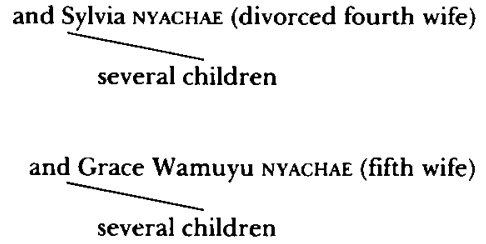

* It is contrary to Gusii custom to enumerate one's children. Therefore, out of respect for the wishes of the Nyachae family, specific individuals are placed on this genealogical chart only if they are mentioned in or were interviewed for this study. 